\section{UF | FLORIDA}

IFAS Extension

Mailing Address (please print)

Phone

Name Address

City

FL Zip

E-Mail *

IFAS Analytical Services Laboratories

Extension Soil Testing Laboratory

PO Box 110740 / Wallace Building 631, UF I Gainesville, FL 32611-0740 EMAIL: SOILSLAB@IFAS.UFL.EDU WEBSITE: SOILSLAB.IFAS.UFL.EDU

\title{
Water Test Information Sheet
}

\section{Note: This Lab Only Tests Samples from the State of Florida.}

Direct any questions regarding this test or the interpretation of the results to your county Extension Agent.
NOTE: These tests will not determine if the water is suitable for human consumption. Bacteriological tests may be available from the County Health Department or from select commercial laboratories.

* In order to expedite reporting of results; please provide an e-mail address if possible.

\begin{tabular}{|c|c|c|c|c|c|c|c|c|c|c|c|c|c|c|}
\hline \multicolumn{15}{|c|}{ Fill in all requested information, using one line per sample and additional sheets for more than 5 samples. } \\
\hline \multirow{4}{*}{ Lab Use Only } & \multirow{4}{*}{ Sample ID } & \multirow{4}{*}{ County } & \multirow{4}{*}{$\begin{array}{l}\text { Crops to be } \\
\text { grown }\end{array}$} & \multicolumn{5}{|c|}{ Water Source Information } & \multicolumn{4}{|c|}{ Water Use Information } & \multicolumn{2}{|c|}{ Cost } \\
\hline & & & & \multirow{3}{*}{$\begin{array}{c}\text { Well } \\
\text { Check }\end{array}$} & \multirow{2}{*}{\multicolumn{3}{|c|}{ If well, specify location \& depth }} & \multirow{3}{*}{$\begin{array}{c}\begin{array}{c}\text { Surface } \\
\text { ditch or } \\
\text { pond }\end{array} \\
\text { Check }\end{array}$} & \multirow{3}{*}{$\begin{array}{l}\text { General } \\
\text { Household } \\
\text { Use }\end{array}$} & \multicolumn{3}{|c|}{ Irrigation } & \multirow{3}{*}{$\begin{array}{l}\text { Irrigation } \\
\text { and micro- } \\
\text { irrigation }\end{array}$} & \multirow{3}{*}{ Household } \\
\hline & & & & & & & & & & \multirow{2}{*}{ Household } & \multirow{2}{*}{$\begin{array}{l}\text { Overhead } \\
\text { or seep }\end{array}$} & \multirow{2}{*}{$\begin{array}{l}\text { Micro- } \\
\text { irrigation }\end{array}$} & & \\
\hline & & & & & Range & Township & Section & & & & & & & \\
\hline & & & & & & & & & & & & & $\$ 10.00$ & $\$ 9.00$ \\
\hline & & & & & & & & & & & & & $\$ 10.00$ & $\$ 9.00$ \\
\hline & & & & & & & & & & & & & $\$ 10.00$ & $\$ 9.00$ \\
\hline & & & & & & & & & & & & & $\$ 10.00$ & $\$ 9.00$ \\
\hline & & & & & & & & & & & & & $\$ 10.00$ & $\$ 9.00$ \\
\hline
\end{tabular}

SPECIAL PROBLEMS NOTED:

Check Money Order

Cash

Total

SAMPLES WILL NOT BE PROCESSED WITHOUT PAYMENT.

Please enclose payment and this sheet in the same package as sample(s). Do not send cash through the mail. 


\section{Instructions and Information for the Water Test Information Sheet}

\section{Taking a Representative Water Sample}

Tools

1. A clean plastic bottle holding about 1 pint in which to collect the water sample. Do not use shampoo or detergent bottles since it is difficult to remove all residues. Glass Bottles Are Not Recommended.

2. A corrugated shipping box. These boxes (also used to mail soil samples) are available free of charge at your local county Cooperative Extension Service office.

3. Some packing material with which to pack the sample to avoid damage or leakage during shipment to the Extension Soil Testing Laboratory.

4. This form. Use additional copies if you plan on sending more than 5 water samples.

\section{Sampling}

1. Allow the water source to run from the intended collection point for several minutes.

For household samples, allow the water to flow for several minutes to ensure the water sample is directly from the well. Water that has been standing in the house plumbing for some time is not a representative sample.

For irrigation and microirrigation samples, sampling as close to the water source as possible will ensure that the sample represents the water source. If you are filtering the water, you may wish to sample the water both before and after filtration to assess the effect of the filtering operation. Filtration will only affect the physical characteristics (suspended solids) of the water.
2. Rinse the sample container and its lid several times in the flowing water. Do not use soap or detergent during this rinsing step.

3. Fill the container completely with the flowing water. Leave as little air as possible in the container Tightly seal the lid immediately after filling the container to ensure against leakage.

4. Label the container and pack it carefully in the prelabeled shipping box.

5. Include in the shipping box:

- Your labeled water sample(s)

- This Water Test Information Sheet with all the requested information on page 1 of the form completed

- A check or money order payable to: University of Florida.

Mail your sample to:

IFAS Analytical Services Laboratories

Extension Soil Testing Laboratory

PO Box 110740

Wallace Bldg. 631

Gainesville, FL 32611-0740

\section{Water Testing - An aid to problem diagnosis}

The physical and chemical determinations made by the Extension Soil Testing Laboratory can be effectively used to diagnose potential problems in water. However, the lab does not test a water's suitability for human consumption. Bacteriological tests may be available from the County Health Department or from selected commercial laboratories.

\section{Test results}

The test report will be emailed / mailed to you within 5 to 10 days after your sample arrives at the Extension Soil Testing Laboratory. Contact your county Extension office if you have questions concerning your results.

\begin{tabular}{|l|l|l|}
\hline \multicolumn{2}{|c|}{ Potential Water Quality Problems } \\
\hline Tests & Irrigation (including microirrigation) & Household \\
\hline $\mathrm{Ca}, \mathrm{Mg}, \&$ total carbonates & liming potential / plugging problems & hardness \\
\hline $\mathrm{Fe} \& \mathrm{Mn}$ & foliage stains / plugging problems & Staining, taste \\
\hline $\mathrm{Na} \& \mathrm{Cl}$ & salt water intrusion, plant damage & salt water intrusion \& landscape plant damage \\
\hline Electrical conductivity & plant damage from high salt content & plant damage from high salt content \\
\hline $\mathrm{pH}$ & corrosion potential / plugging & corrosion \\
\hline Suspended solids & plugging problems & - \\
\hline
\end{tabular}

